Respiration 1993;60(suppl 1):I-V

\title{
Contents, Vol. 60, Supplement 1, 1993
}

\section{Petrikkos, G.L. Introduction 1}

Höfiken, G. Clinical Requirements in the Treatment of Today's Respiratory Tract Infections 3 Cullmann, W. Importance of Beta-Lactamase Stability in Treating Today's Respiratory Tract Infections 10

König, W. Role of the Immune System in Recovery from Infection 16

Scheffer, J.; König, W. Cephalosporins and Inflammatory Host Reactions 25

Kneer, J. Relevance of Antibiotic Tissue Penetration in Treating Respiratory Tract Infections 32

Dagan, R. Antibiotic Treatment of Pediatric Community-Acquired Lower Respiratory Tract Infections: Challenges and Possible Solutions 38

Kissling, M.; Chadbourne, U. Literature Survey on Clinical Efficacy and Tolerability on Cefetamet Pivoxil: An Analysis of 3,128 Cases 45

Petrikkos, G.L. Concluding Remarks 55

Author Index 57

Subject Index 57

$\mathrm{V}$

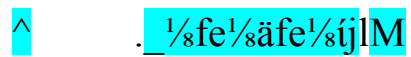

